\title{
PENERAPAN STRATEGI REACT TERHADAP PENINGKATAN AKTIVITAS SISWA SMK NEGERI 1 PAINAN
}

\author{
TITI SUMARNI \\ Universitas Tamansiswa Padang \\ titisumarni0909@gmail.com
}

\begin{abstract}
As mathematic teacher, we should be able to create an interesting and active learning, beside that she should be able to create a good competition in the class. It has positive effect to gain optimum study result. Teacher should use variation method and learning strategy in learning so that teaching and learning become easy and fun for the student. The student will be more active and have motivation to study. The implementation of REACT strategy for student of XI TKJ SMK Negeri 1 Painan is suitable to improve students activity in learning. The research is classroom action research which consist of two cycles, each cycles involve four stages : (1) planning, (2) acting, (3) observing, and (4) reflecting. The sample of the research are 34 student. The data is collected by using observation paper. The analysis of data is done by using descriptive qualitative. The result of the students activity in asking question in cycle I is $43 \%$ and in cycle II is 54\%. It means that the activity in asking question achieve avarage level. The activity in giving sugestion or giving opinion also get on avarage level in cycle 1 is $28 \%$ and in cycle II is 43\%. The activity in group discussing get high level.It happened in cycle I anda cycle II .They have same percentage. It is $67 \%$.
\end{abstract} Keywords: Activity, Strategi REACT

\begin{abstract}
Abstrak: Sebagai guru matematika, kita harus bisa menciptakan pembelajaran yang menarik dan aktif, selain itu dia harus mampu menciptakan kompetisi yang baik di kelas. Ini memiliki efek positif untuk mendapatkan hasil studi yang optimal. Guru harus menggunakan metode variasi dan strategi belajar dalam pembelajaran sehingga mengajar dan belajar menjadi mudah dan menyenangkan bagi siswa. Siswa akan lebih aktif dan memiliki motivasi untuk belajar. Implementasi strategi REACT untuk siswa XI TKJ SMK Negeri 1 Painan cocok untuk meningkatkan aktivitas siswa dalam pembelajaran. Penelitian ini adalah penelitian tindakan kelas yang terdiri dari dua siklus, setiap siklus melibatkan empat tahap: (1) perencanaan, (2) akting, (3) mengamati, dan (4) refleksi. Sampel penelitian adalah 34 siswa. Data dikumpulkan dengan menggunakan kertas observasi. Analisis data dilakukan dengan menggunakan deskriptif kualitatif. Hasil aktivitas siswa dalam mengajukan pertanyaan pada siklus I adalah $43 \%$ dan pada siklus II adalah 54\%. Ini berarti bahwa aktivitas dalam mengajukan pertanyaan mencapai tingkat rata-rata. Aktivitas dalam memberikan sugestion atau memberikan pendapat juga pada tingkat rata-rata pada siklus 1 adalah $28 \%$ dan pada siklus II adalah $43 \%$. Aktivitas dalam kelompok mendiskusikan mendapatkan level tinggi. Hal ini terjadi pada siklus I dan siklus II. Mereka memiliki persentase yang sama. $67 \%$.
\end{abstract}

Kata kunci: Aktivitas, Strategi REACT.

\section{A. Pendahuluan}

Matematika memiliki fungsi sebagai pengembang dalam kemampuan berkomunikasi dengan menggunakan simbol-simbol serta penalaran yang membantu memperjelas dan menyelesaikan permasalahan dalam kehidupan sehari-hari. Dengan 
katakan lain bahwa matematika merupakan salah satu cabang dari mata pelajaran yang mampu memacu kecerdasan dan kekritisan siswa. Hal ini sesuai yang dijelaskan dalam Standar Isi KTSP Kurikulum mata pelajaran Matematika SMK, tujuan pembelajaran matematika adalah : Memahami konsep matematika, menggunakan penalaran, memecahkan masalah, mengkomunikasikan gagasan dengan simbol tabel dan diagram atau media lain. Dari penjelasan di atas dapat kita simpulkan bahwa pelajaran matematika sangat penting dikuasai oleh siswa. Dengan menguasai matematika dapat membantu siswa dalam mengembangkan potensi intelektual yang ada dalam dirinya. Disamping itu dengan menguasai matematika siswa dapat dengan mudah mempelajari bidang-bidang ilmu lain.

Berdasarkan pengamatan penulis selama observasi di SMK Negeri 1 Painan dapat dikatakan bahwa penguasaan matematika siswa masih rendah, dan keaktifan siswa masih kurang. Hal ini disebabkan karena ada sebagian pembelajaran matematika di kelas masih berlangsung secara konvensional, yaitu guru masih menjelaskan konsep diikuti dengan pemberian contoh soal kemudian siswa disuruh mengerjakan soal-soal seperti contoh yang telah diberikan. Suasana pembelajaran di dalam kelas tidak komunikatif. Siswa tidak kreatif, seandainya ada soal yang tidak dapat dikerjakan, mereka cenderung untuk diam saja. Mereka tidak ingin bertanya dan enggan untuk meminta bantuan pada temannya karena malu dan takut ditertawakan. Hal ini dapat dilihat dari siswa yang bertanya dan mengerjakan latihan kedepan kelas hanya beberapa orang dan selaluorang yang sama, sehingga pembelajaran tidak menarik bagi siswa.

Untuk itu perlu usaha dalam mengoptimalkan proses pembelajaran tersebut. Salah satu usaha tersebut adalah dengan menggunakan strategi REACT (Relating, Experiencing, Applying, Cooperating, Transfering). Strategi ini adalah strategi pembelajaran dengan pendekatan kontekstual terdiri lima strategi yaitu : (1) Relating (mengkaitkan), (2) Experiencing (mengalami), (3) Applying (menerapkan), (4) Cooperating (bekerjasama), (5) Transffering (mentransfer). Relating (mengkaitkan) adalah belajar dalam konteks pengalaman kehidupan nyata atau pengetahuan yang sebelumnya. Experiencing (mengalami) merupakan strategi belajar dengan belajar melalui explorasi, penemuan dan penciptaan. Berbagai pengalaman dalam kelas dapat mencakup penggunaan manipulatif, aktivitas pemecahan masalah dan laboratorium. Applying (menerapkan) adalah belajar dengan menempatkan konsep-konsep untuk digunakan, dengan memberikan latihan-latihan yang realistik dan relevan. Cooperating (bekerjasama) adalah belajar dalam konteks sharing, merespon dan berkomunikasi dengan para pembelajar lainnya.

Kemudian Transffering (mentransfer) adalah belajar dengan menggunakan pengetahuan dalam konteks baru. Oleh sebab itu Penulis ingin menerapkan strategi REACT pada siswa SMK Negeri 1 Painan. Penulis ingin melihat melihat peningkatan aktivitas siswa. Khususnya pada materi program linier. Untuk itu dilakukan penelitian dengan judul "Peningkatan Aktivitas dengan Penggunaan Strategi REACT Pada Siswa SMK Negeri 1 Painan". Penulis memilih strategi ini karena strategi ini dapat meningkatkan akivitas siswa sesuai dengan Center of Occupational Research and Development (1999), maka aktivitas guru dan siswa dalam pelaksanaan strategi REACT dapat dilihat sebagai berikut: 
Tabel 1. Aktivitas siswa dalam pelaksanaan strategi REACT

\begin{tabular}{|l|l|l|}
\hline Aspek REACT & Kegiatan Guru & Kegiatan Siswa \\
\hline Relating & $\begin{array}{l}\text { Guru memberi pertanyaan } \\
\text { yang dapat membuat siswa } \\
\text { untuk mengkaitkan materi } \\
\text { yang sedang dipelajari dengan } \\
\text { materi sebelumnya dan dengan } \\
\text { kehidupan sehari-hari. }\end{array}$ & $\begin{array}{l}\text { Siswa mencari ide-ide matematika } \\
\text { yang berhubungan dengan } \\
\text { pertanyaan yang diajukan oleh guru, } \\
\text { serta memahami bagaimana ide-ide } \\
\text { tersebut dapat saling koneksi }\end{array}$ \\
\hline Experiencing & $\begin{array}{l}\text { Guru memberikan LKS kepada } \\
\text { setiap kelompok untuk } \\
\text { didiskusikan dengan tujuan } \\
\text { siswa dapat melatih diri } \\
\text { mengkonstruksi } \\
\text { pemahamannya sendiri }\end{array}$ & $\begin{array}{l}\text { Siswa berdiskusi mencari konsep- } \\
\text { konsep yang berhubungan dengan } \\
\text { permasalahan yang ada pada LKS } \\
\text { dengan cara membaca buku, serta } \\
\text { memahami bagaimana konsep- } \\
\text { konsep tersebut dapat digunakan } \\
\text { secara tepat dalam proses pemecahan } \\
\text { masalah yang ada pada LKS tersebut. }\end{array}$ \\
\hline Applying & $\begin{array}{l}\text { Guru memberi latihan soal } \\
\text { cerita yang sifatnya realistik } \\
\text { dan relevan }\end{array}$ & $\begin{array}{l}\text { Siswa mencari ide-ide yang dapat } \\
\text { diterapkan untuk menyelesaikan soal } \\
\text { cerita tersebut, serta berpikir } \\
\text { bagaimana menggunakan ide-ide itu } \\
\text { secara tepat. }\end{array}$ \\
\hline Cooperating & $\begin{array}{l}\text { Guru membagi kelas menjadi } \\
\text { beberapa kelompok secara } \\
\text { heterogen }\end{array}$ & $\begin{array}{l}\text { Siswa mengkondisikan diri untuk } \\
\text { berkumpul dengan kelompoknya, } \\
\text { kemudian berdiskusi dan } \\
\text { mengerjakan LKS secara bersama. }\end{array}$ \\
\hline Transfering & $\begin{array}{l}\text { Guru memberikan latihan soal } \\
\text { berupa soal bidang ilmu lain }\end{array}$ & $\begin{array}{l}\text { Siswa mencari ide-ide yang } \\
\text { berhubungan dengan bidang ilmu } \\
\text { lain, serta memahami bagaimana } \\
\text { menggunakan ide-ide itu dalam } \\
\text { proses penyelesaian soal. }\end{array}$ \\
\hline
\end{tabular}

Keaktifan siswa adalah suatu hal yang penting yang harus diperhatikan oleh guru selama proses belajar mengajar. Apabila siswa aktif dalam proses pembelajaran atau besar keterlibatannya dalam proses belajar mengajar maka semakin besar mereka mengalami proses belajar, dengan demikian otomatis hasil belajar siswa akan meningkat sehingga dapat mencapai hasil yang optimal. Sesuai dengan pendapat Sadirman (2007 : 100) mengemukakan bahwa aktivitas belajar adalah kegiatan atau aktivitas yang bersifat fisik maupun mental, yaitu berbuat dan berpikir sebagai suatu rangkaian yang tidak dapat dipisahkan. Jadi segala sesuatu yang dilakukan atau kegiatan-kegiatan yang terjadi fisik maupun mental, merupakan suatu aktivitas.

Menurut Paul D Dierich (dalam Hamalik 2001 : 172) ada beberapa jenis aktivitas adalah: 1) Kegiatan-kegiatan visual : Membaca, melihat gambar-gambar, mengamati eksperimen, demonstrasi, pameran, dan mengamati orang lain bekerja atau bermain. 2) Kegiatan-kegiatan lisan (oral) : Mengemukakan suatu fakta atau prinsip, menghubungkan suatu kejadian, mengajukan pertanyaan, memberi saran, mengemukakan pendapat, wawancara, diskusi, dan interupsi. 3) Kegiatan-kegiatan mendengarkan: mendengarkan penyajian bahan, mendengarkan percakapan atau diskusi kelompok, mendengarkan suatu permainan, mendengarkan radio. 4) Kegiatankegiatan menulis : menulis cerita, menulis laporan, memeriksa karangan, bahan-bahan 
kopi, membuat rangkuman, mengerjakan tes, dan mengisi angket. 5) KegiatankegiatanmenggambarMenggambar, membuat grafik, chart, diagram peta, dan pola. 6) Kegiatan-kegiatan metrik : melakukan percobaan, memilih alat-alat, melaksanakan pameran, membuat model, menyelenggarakan permainan, menari dan berkebun. 7) Kegiatan-kegiatan mental : merenungkan, mengingat, memecahkan masalah, menganalisis faktor-faktor, melihat hubungan-hubungan, dan membuat keputusan. 8) Kegiatan-kegiatan emosional : minat, membedakan, berani, tenang, dan lain-lain. Kegiatan-kegiatan dalam kelompok ini terdapat dalam semua jenis kegiatan dan overlap satu sama lain. Sedangkan menurut Slameto (2010 : 36) Aktivitas belajar merupakan kegiatan siswa dalam berpikir dan berbuat, berupa kegiatan bertanya, mengajukan pendapat, dan menimbukan diskusi dengan guru. Bila siswa menjadi partisipan yang aktif, maka ia mendapat pengetahuan itu dengan baik.

Dari beberapa pengertian aktivitas di atas maka penulis mengambil beberapa jenis aktivitas untuk melihat aktivitas siswa yang diinginkan selama proses belajar mengajar yaitu: 1) Siswa mengajukan pertanyaan, 2) Siswa memberi saran atau mengemukakan pendapat, dan 3) Siswa berdiskusi dalam kelompok

\section{B. Metodologi Penelitian}

Jenis penelitian ini adalah Penelitian Tindakan Kelas (PTK) atau classroom Action Research. PTK berorientasi pada pemecahan masalah dan penggunaan suatu strategi yang berisfat inovatif dalam memecahkan masalah. Karena itu, didalam PTK selalu terdapat padanan antara masalah dan pemecahan masalah. Seperti yang dinyatakan oleh Anas Yasin (2002 : 6) penelitian tindakan kelas merupakan suatu bentuk penelitian terapan yang bertujuan untuk melakukan perubahan dalam proses pembelajaran, secara sederhana PTK adalah studi tentang situasi kelas dengan tujuan untuk memperbaiki dan meningkatkan mutu proses pembelajaran.Prosedur yang akan dilakukan dalam penelitian adalah berbentuk siklus, dimana setiap siklus dalam PTK mempunyai 4 kegiatan pokok yaitu : rencana (plan), tindakan (action), pengamatan (observation), dan refleksi (reflection).

\section{Hasil dan Pembahasan}

Penelitian ini dilaksanakan sebanyak dua siklus.Siklus IAnalisis data hasil obsrvasi pada siklus Idapat dilihat pada tabel 2 di bawah ini :

Tabel 2. Hasil Pengamatan Aktivitas Siswa Pada Siklus I

\begin{tabular}{|c|c|c|c|c|c|c|c|c|}
\hline \multirow{2}{*}{ No } & \multirow{2}{*}{$\begin{array}{l}\text { Aktivitas yang } \\
\text { diamati }\end{array}$} & \multicolumn{2}{|c|}{$\begin{array}{l}\text { Pertemuan } \\
\text { I }\end{array}$} & \multicolumn{2}{|c|}{$\begin{array}{l}\text { Pertemuan } \\
\text { III }\end{array}$} & \multicolumn{2}{|c|}{ Pertemuan V } & \multirow{2}{*}{$\begin{array}{l}\text { Rata- } \\
\text { Rata }\end{array}$} \\
\hline & & Jumlah & $\%$ & Jumlah & $\%$ & Jumlah & $\%$ & \\
\hline 1 & $\begin{array}{l}\text { Mengajukan } \\
\text { pertanyaan }\end{array}$ & 11 & 37 & 14 & 45 & 15 & 48 & 43 \\
\hline 2 & $\begin{array}{l}\text { Memberikan saran } \\
\text { atau mengemukakan } \\
\text { pendapat }\end{array}$ & 7 & 23 & 9 & 29 & 10 & 32 & 28 \\
\hline 3 & Berdiskusi dalam & 19 & 63 & 20 & 65 & 23 & 74 & 67 \\
\hline
\end{tabular}




\begin{tabular}{|l|l|l|l|l|l|l|l|l|}
\hline kelompok & & & & & & & \\
\hline Jumlah Yang Hadir & 30 & 31 & 31 & & \\
\hline
\end{tabular}

Dari tabel 2 di atas menunjukkan bahwa rata-rata aktivitas siswa mengajukan pertanyaan berada pada tingkat sedang, aktivitas siswa memberikan saran atau mengemukakan pendapat berada pada tingkat rendah, sedangkan aktivitas siswa berdiskusi dalam kelompok berada pada tingkat tinggi. Dari ketiga aktivitas siswa tersebut maka yang perlu ditingkatkan adalah aktivitas memberikan saran atau mengemukakan pendapat.

Siklus II. Analisis data hasil obsrvasi pada siklus Idapat dilihat pada tabel 3 di bawah ini :

\section{Tabel 3. Hasil Pengamatan Aktivitas Siswa Pada Siklus II}

\begin{tabular}{|c|c|c|c|c|c|c|}
\hline \multirow{2}{*}{ No } & \multirow{2}{*}{$\begin{array}{l}\text { Aktivitas } \\
\text { diamati }\end{array}$} & \multicolumn{2}{|c|}{ Pertemuan VIII } & \multicolumn{2}{|c|}{ Pertemuan X } & \multirow{2}{*}{$\begin{array}{l}\text { Rata- } \\
\text { Rata }\end{array}$} \\
\hline & & Jumlah & $\%$ & Jumlah & $\%$ & \\
\hline 1 & $\begin{array}{l}\text { Mengajukan } \\
\text { pertanyaan }\end{array}$ & 15 & 47 & 19 & 61 & 54 \\
\hline 2 & $\begin{array}{l}\text { Memberikan saran atau } \\
\text { mengemukakan } \\
\text { pendapat }\end{array}$ & 12 & 38 & 15 & 48 & 43 \\
\hline 3 & $\begin{array}{l}\text { Berdiskusi dalam } \\
\text { kelompok }\end{array}$ & 20 & 63 & 22 & 71 & 67 \\
\hline \multicolumn{2}{|c|}{ Jumlah Yang Hadir } & \multicolumn{2}{|l|}{32} & \multicolumn{2}{|l|}{31} & \\
\hline
\end{tabular}

Dari tabel 3 di atas menunjukkan bahwa rata-rata aktivitas siswa mengajukan pertanyaan dan memberikan saran atau mengemukakan pendapat berada pada tingkat sedang, sedangkan aktivitas siswa berdiskusi dalam kelompok berada pada tingkat tingggi. Dari ketiga aktivitas siswa tersebut terlihat aktivitas siswa mengajukan pertanyaan dan memberikan saran atau mengemukakan pendapat sudah mengalami peningkatan, sedangkan untuk aktivitas siswa berdiskusi dalam kelompok tidak mengalami peningkatan. Walaupun begitu semuanya masih dalam batas yang cukup wajar, karena semuanya masih dalam kategori sedang dan tinggi

Penerapan strategi REACT telah dilaksanakan di kelas XI TKJ SMK Negeri 1 Painan. Hasil penerapan strategi pembelajaran ini terlihat dari peningkatan aktivitas. Berikut ini dijelaskan masing-masing aktivitas: Pertama. Aktivitas siswa mengajukan pertanyaan. Kesadaran siswa akan proses berfikir terlihat jelas ketika siswa memonitor dan mengontrol proses berpikirnya, kemudian siswa tersebut menyadari bahwa sesungguhnya belum sepenuhnya memahami suatu konsep atau strategi pemecahan masalah matematika, maka siswa tersebut bertanya kepada gurunya. Sikap siswa lebih positif terhadap pembelajaran matematika, ini terlihat waktu proses pembelajaran berlangsung dan dari hasil observasi. Untuk menggali kesadaran yang demikian tentu harus dengan menggunakan strategi pembelajaran yang tepat. Strategi REACT sangat berpotensi untuk itu, sehingga dalam penelitian ini aktivitas siswa bertanya kepada guru menempati katagori yang baik. Hal ini menunjukkan bahwa kesadaran berfikir siswa akan semakin baik ketika siswa belajar dengan menggunakan strategi REACT. 
Kedua, aktivitas siswa memberikan saran atau mengemukakan pendapat. Pada aktivitas ini selalu mengalami peningkatan dari awal sampai akhir penelitian yaitu berada pada kategori sedang atau baik. Ini berarti sosialisasi antara siswa semakin baik, ketika salah satu siswa maju ke depan kelas menuliskan jawabannya. Siswa yang lain menanggapi, ini terlihat adanya interaksi sesama siswa sudah semakin baik.

Ketiga, aktivitas berdiskusi dalam kelompok. Aktivitas ini, siswa sudah menunjukkan sikap untuk mau bekerjasama dalam kelompok untuk menyelesaikan tugas yang menjadi tanggung jawab bersama dalam kelompoknya. Pada pertemuan akhir penelitian terlihat aktivitas ini berada pada kategori tinggi.

\section{Penutup}

Dari hasil penelitian di atas dapat disimpulkan bahwa Pembelajaran dengan menggunakan strategi REACT dapat meningkatkan aktivitas siswa kelas XI TKJ SMK Negeri 1 Painan. Aktivitas mengajukan pertanyaan pada siklus I adalah $43 \%$ dan pada siklus II adalah 54\%. Ini berarti aktivitas mengajukan pertanyaan mencapai kategori sedang. Aktivitas memberikan saran atau mengemukakan pendapat mencapai kategori sedang dimana pada siklus I adalah $28 \%$ dan pada siklus II adalah $43 \%$. Aktivitas berdiskusi kelompok mencapai kategori tinggi dimana siklus I dan siklus II adalah sama $67 \%$.

\section{Daftar Pustaka}

Anas Yasin. 2002. Penelitian Tindakan Kelas : Tuntunan Praktis.Padang: Sukabina.

Center of Occupational Research and Development. (1999). Teaching Mathematics Contextually. Tersedia: http://www.cord.org

Dimyati dan Mudjono. 2006. Belajar dan Pembelajaran. Jakarta : Rineka Cipta.

Hamalik, Oemar. 2001. Proses Belajar Mengajar. Bandung : Penerbit Bumi Aksara.

Sardiman. 2007. Interaksi\&Motivasi Belajar Mengajar.Jakarta: PT RajaGrafindo Persada.

Slameto. 2010. Belajar dan Faktor yang Mempengaruhi.Jakarta: Asdi Mahasatya

Sudjana, 1990. Metoda Statistika. Bandung: Tarsito. 